\footnotetext{
Susanne Gehrmann

Susanne Gehrmann is Assistant

Professor in African Literatures and Cultures at Humboldt University, Berlin. Her research areas are Senegalese and Congolese literatures, autobiography and colonial discourse. In 2008 she was Feodor-Lynen-Fellow at Université Laval, Canada. ${ }^{1}$

E-mail: susanne.gehrmann@rz.hu-berlin.de
}

\section{Remembering colonial violence: Inter/textual strategies of Congolese authors}

\title{
Remembering colonial violence: Inter/textual strategies of Congolese authors
}

This article explores the Congolese remembering of the experienced colonial violence through the medium of literature. Although criticism of colonialism is not a favourite topic of Congolese writers, there exists an important corpus of texts, especially when the literary production of Congo Kinshasa and Congo Brazzaville with their politically distinct though sometimes similar experiences is taken into account. Three main strategies of writing about the topic can be distinguished: a documentary mode, an allegorical mode and a fragmented mode, which often appear in combination. Intertextuality with the colonial archive as well as oral African narrations is a recurrent feature of these texts. The short stories of Lomami Tchibamba, of the first generation of Congolese authors writing in French, are analysed as examples for a dominantly allegorical narration. Mythical creatures taken from the context of oral literature become symbols for the process of alterity and power relations during colonialism, while the construction of a heroic figure of African resistance provides a counter-narrative to colonial texts of conquest. Thomas Mpoyi-Buatu's novel La reproduction (1986) provides an example of fragmented writing that reflects the traumatic experience of violence in both Congolese memory of colonialism and Congolese suffering of the present violent dictatorial regime. The body of the protagonist and narrator becomes the literal site of remembering. Key words: Congolese literature in French, colonial violence, memory, allegory, fragmentation, body.

\section{Violence, literature, memory}

100 years after the beginning of official Belgian colonisation in the Congo, and some 130 years after the onset of Leopold's "Congo Free State," notorious for its violent exploitation of both populations and resources of the land, it is astonishing to consider the ongoing literary production on the Congo. Since Joseph Conrad's paradigmatic Heart of Darkness (1902), the fascination with the Congo as an imaginary space filled with overwhelming nature, unspeakable violence and human nature at its extreme, has continued to move European and American authors far beyond the colonial period. Some of those texts, such as Lieve Joris' travel writings, Barbara Kingsolver's The Poisonwood Bible (1998) or John Le Carré's The Mission Song (2006) are widely read. At the same time, the growing corpus of literature by Congolese authors, apart from a few books in the local languages mainly published in French, is by far not as well known as some of the Western writings on the Congo. Recently, new overview stud- 
ies like those of Silvia Riva (2006) and Djungu-Simba (2007) have proved the richness of the literature of the Democratic Republic of the Congo (DRC) today - in spite of all the difficulties that the ongoing political repression and economic disaster of the country may cause to writers, and artists in general. ${ }^{2}$ But the power relations between the Congo and the rest of the world are still affected by the lasting effects of colonialism and neo-colonialism, not only with regard to economic relations, but with regard to cultural relations as well. Who holds discursive power over the Congo, its history and future?

It is worthwhile to remember that the first wave of fictional writing about the Congo came into being with the debate about the "Congo atrocities" in King Leopold's Congo Free State. Beyond the political conflict among the European colonial powers, the testimonial publications of eye-witnesses of colonial violence and the journalistic engagement of the Congo Reform Association (Hochschild 1998), writers all over Europe and in the United States turned the subject into material for literary fiction (Gehrmann 2003, 2005). The Congo was notorious as a place of excessive violence "among the natives" as well as "upon the natives"; it became a synecdoche for Africa or the tropics in general and a metaphor for human folly, cruelty and excess. This discourse dominates the Western literary production still today. The intertextual linking to Conrad, as the most refined literary representative of an imaginary Congo is again and again obvious, and - as in the above-mentioned recent novels by Kingsolver and Le Carré, which focus on the figure of the missionary - Africans still play but an accessory role in these novels.

However, what about Congolese writers? How do they, if at all, represent the violent history of the Congo, how do they remember the traumatic experiences of colonialism, both physical and structural, in fiction? In general, Congolese authors are more inclined to place their writing in a context of immediate history and colonialism is not a dominant theme in Congolese literature from the DRC. Tshitungu Kongolo (2002) explains some of the historical and political reasons: Belgian cultural politics during colonialism, Mobutu's call for authenticité in the 1970s, the urgency of the dictatorial situation in the 1980s. And yet, there exists a small corpus of texts about colonial violence that spans the period from the first generation of francophone Congolese writers to its contemporary representatives. With this article, which will introduce some of these texts and analyse their strategies of enunciation and narration, I would like to stress that it is not only observers and outsiders, but Congolese authors themselves who speak out about colonial violence. ${ }^{3}$

At this point of my introduction, I would also like to mention that it is not always useful to distinguish between the literatures of the two Congos, the Republic (capital Brazzaville) and the Democratic Republic (capital Kinshasa), the former Zaïre, as if they were separated entities. Not only has the concept of national literatures been contested for the African context in general (see Thomas 2002), but it must also be 
considered that the two capital cities Brazzaville and Kinshasa are bound together geographically and share a vivid cultural life. There is an ongoing flow of the population from one side of the Congo River to the other and authors such as Lomami Tchibamba, Henri Lopes or Sony Labou Tansi are attached to and wrote about both Congos. Meanwhile, it remains true that the historical and cultural differences between French and Belgian colonialism are complex. The fact that the Francophone literature of Congo Brazzaville is much more prolific than that of the DRC is a result of different cultural policies during colonialism and post-colonialism. Nevertheless, there are also similarities between the histories of the two countries, especially when we think about the violence of the early colonial period with its rubber exploitation and railway constructions. With respect to the focus of this volume, I will concentrate on authors and texts from the DRC here, and only mention briefly some names from

"the other side of the river."

\section{Realistic, allegorical and fragmented modes of representation}

Considering the corpus of fictional Congolese texts with references to the violence of colonialism, I propose a rough distinction between three major modes of enunciation of the problem: (a) realistic narration, (b) allegorical narration, and (c) fragmented narration. These three basic stylistic features can either be dominant in one text or, more often, appear in combination. Examples of texts, dominated by the realistic style, are Lomami Tchibamba's novels Ngemena (Ngemena is the name of a town, 1981) and Ah! Mbongo (Ah! Money, posthumously published in 2007), as well as Emmanuel Dongala's novel Le feu des origines (The fire of origins, 1987). Broadly speaking, these novels draw on a historically and socially determined setting as well as the model of the classical realistic novel attached to the destiny of one protagonist and his family. Through this metonymic narrative of one particular destiny, which is meant to be representative for history in general, an African point of view is focused on in order to elaborate a quasi-documentary portrait of colonial society with its inherent structural violence. The term "documentary" does not mean that the text is less fictional; rather it characterizes the deliberate use of historical details, often digressing from the main story of the novel. For instance, the long explanations about the system of the évolués in Ngemena or the functioning of religious groups digress from the main story. At the same time, the details contextualise and historicise the narration of the story of one évolué who travels the country and becomes an eyewitness to the suppression of Christian religious movements among the Congolese population. The first intellectual elite of the Belgian Congo - in the sense of Western education - could be promoted to the status of évolué by the colonial authorities (Riesz 1998: 322-26). Paradoxically, colonial settlers at the same time often despised these "promoted" African people. The humiliations of the évolués as a particular group within the colonial system are 
Tchibamba's focus in the novel, which has been considered as autobiographical (Mulumba 2007). The title itself, Ngemena, refers to a place where disciples of Congolese Christian movements, considered subversive by the Belgian administration, were banned. Throughout Tchibamba's novel, we thus find perfect examples of the problem of colonial mimicry as a space of ambiguity, following the concept of Homi Bhabha (1994). On the one hand, colonisers would like their colonial subjects to become as "Christian" and as "civilised" as them. On the other hand, the colonised, who mimic the Western model all too well, are considered dangerous. In fact, they challenge the colonial order, because if the colonised becomes too "civilised" and even a more devout Christian than his or her master, the coloniser's justification of the colonial project as "civilisation process" loses its validity.

$[\mathrm{M}]$ imicry emerges as the representation of a difference that is itself a process of disavowal. Mimicry is thus the sign of a double articulation: a complex strategy of reform, regulation and discipline, which "appropriates" the Other as it visualizes power. Mimicry is at the same time also the sign of the inappropriate, however, a difference or recalcitrance, which coheres the dominant strategic function of colonial power, intensifies surveillance, and poses an immanent threat to both "normalized" knowledges and disciplinary powers. The effect of mimicry on the authority of colonial discourse is profound and disturbing. (Bhabha 1994: 86)

In Tchibamba's novel the specific structural violence against the "mimic men" in the case of the Belgian Congo unfolds through the accurate description of how the évolués were given certain rights and privileges only to be subjected to an arbitrary regime of surveillance, suppression and cynical mockery thereafter. His accusation of Belgian colonialism is straightforward (Abomo-Maurin 1995).

In his earlier short narrations or nouvelles to use the French generic term, Tchibamba already uses a realistic style, but in combination with a dominating allegorical narration that gives a much more ambivalent dimension to these texts. As examples of allegorical writing, I will present and analyse the two texts "La récompense de la cruauté" (The vengeance for cruelty) and "N'Gobila des Mswata ou Mistantèle" (N'Gobila of the Mswata or Mistantèle), published by Lomami Tchibamba in 1972 in my next section. A further example of a combination of realistic and allegorical narration is Sylvain Bemba's drama Tarantelle noir et diable blanc (Black Tarantella and white devil, 1976). Drawing on the Faust motif, the story of the colonialist Mr. Faustino who buys African souls gives an allegorical framework to the story of two generations of a Congolese family, who experiences various forms of colonial suppression and violence. Moreover, the genre of the drama draws on a multitude of metaphors used throughout the text, of which animal metaphors are outstanding. Colonialism appears in the image of the tarantella spider spinning its inescapable webs, but the dance of the Tarentelle (of Italian origin) is praised as a form of liberating resistance. 
This sub-allegory structures the text further, while at the same time the narrative and dialogic passages about violent colonial practices give a rather realistic, though sometimes hyperbolic image of the historical setting.

Yet a different and literally speaking radical use of the allegorical mode can be found in Pius Ngandu Nkashama's short novel Yakouta (1995, Yakouta is a woman's name). Here, the figure of a handicapped, tortured and violated woman who becomes a messianic guide to her people, against all odds, can be read as an allegory for the Congo, its violent history and its hope for a better future. Although Nkashama is best known for his criticism of Mobutu's dictatorial regime, this text avoids concrete historical references, using instead imagery and allusions which point to several superimposed semantic levels. In this sense, Nkashama's Yakouta is at the same time representative of what I call fragmented narration, a style that overturns realistic writing through disruptions and uses language as a marker of unspeakable experiences, uncured ills and unforgettable violence throughout Congolese history. It subverts chronology and coherence in time, space and characters. Nkashama's narration is purely abstract. The figure of the repressive political power in Yakouta is called le roi dément (the mad king), a name which gives way to more than one semantic level: he can be decoded as Mobutu or Leopold II, or any other mad dictator. The figure of the weak woman who becomes a symbol of resistance and liberation also reminds the reader of the historical Doña Béatrice, a Congolese prophetess who denounced Portuguese domination in the Congo kingdom during the $17^{\text {th }}$ and $18^{\text {th }}$ centuries. ${ }^{4}$ Given the recent history of war atrocities in Eastern Congo, especially against women, another semantic level can today be added to Nkashama's allegorical text.

A fragmented narration on structural colonial violence is also inscribed in V. Y. Mudimbe's autobiographical work Les corps glorieux des mots et des êtres. Ésquisse d'un jardin africain à la bénédictine (The glorious bodies of words and beings. Sketch of an African garden in the Benedictine style,1994). This text associates essay writing and life writing, it breaks through boundaries of genres and laws of chronology, but clearly exposes some of the mechanisms of the colonial subjection of the African individual, focusing on the apparatus of the Catholic Church as colonial agent in this case. Meanwhile, the text I chose to present here as an example of a fragmented narration about violence is the novel La re-production (The re-production, 1986) by Thomas Mpoyi-Buatu. Written at the climax of Mobutu's dictatorship, the novel stresses the continuation between colonial violence and post-independence violence. Throughout my analysis of Tchibamba and Mpoyi-Buatu, I will also go into the intertextual strategies they use. What seems most interesting here with regard to a dominating motif in the literature about the Congo is the textual confrontation with Joseph Conrad, again present in the texts of both Congolese authors: this time not as continuation of his central metaphors and symbols, but as contestation. 


\section{Lomami Tchibamba's human monsters and the portrayal of colonial society}

The work of Lomami Tchibamba, who has often been called Congo's first novelist, is divided into two periods which Silvia Riva (2006: 80) has called le cycle du merveilleux (the cycle of the fantastical) on the one hand, and the courant picaresque (the picaresque mode) on the other hand. Tchibamba's allegorical narrations of the first period owe much to their intertextual links with orality. As Kadima-Nzuji (1982) has explained, Tchibamba makes strategic use of elements of the oral tradition. In fact, in the narratives of Ngando (The crocodile, 1948), "La récompense de la cruauté" and "N'Gobila des Mswata ou Mistantèle" (1972), the story starts each time with a realistic description of daily life in a colonial society, only to quickly turn into a fantastical mode of narration; to a universe of the magic, ruled by monsters and sorcerers, a universe grounded in popular beliefs familiar to the Congolese reader through oral storytelling. The realism of the modern world is touched by the magical-fantastical elements of a timeless time, out of space. Kadima-Nzuji (1982: 9) speaks of two contrasting spaces of the text, "one realistic, the other mythical, which, because they are intertwined with each other, aptly restore a universe to us where day and night, life and death, the visible and the invisible are coordinated, even integrated symbolically in a close cohesion." ${ }^{5}$ It is indeed striking that the magic creatures and fantastical happenings have at the same time a flavour of reality, as they become part of a historically and geographically well-situated place. This is also the reason why Tchibamba's narratives function so obviously as allegories: the imaginary features of the stories rely on a concrete historical background and appeal to the reader to understand them as figures for something else: they make a statement about colonial society and its inherent violence.

Already the short novel Ngando, which won the first prize at the concours litterraire de la foire coloniale de Bruxelles (Literary contest of the colonial fair in Brussels) in 1948, contained strong scenes of scepticism about the good intentions of colonization. Describing its realistic vein, Nkashama (1982: 154-55) explains, "the author has overcharged his text with elements taken from the daily life of the city of Leopoldville at colonial times, representing thus the real anguish which marked the existence of the colonised." ${ }^{\prime \prime}$ The central trope of the crocodile can be read as an allegory of power in general, and thus unfolds ambiguous meanings in the given context. The crocodile, which carries out the plans of sorcerers against innocent people by stealing their children, can be read as the symbol of a fight between good and evil inside the traditional Congolese framework, an interpretation favoured by Kadima-Nzuji (1984: 233-40) and Halen (2004). Nkashama reads the novel primarily as a narration of initiation within the context of mystical knowledge systems. At the same time, Ngando, the crocodile, could also be a signifier for the colonial power, which steals away children from their parents' authority and culture by sending them to mission schools.

In the two stories "La récompense de la cruauté" and "N'Gobila des Mswata," the criticism of colonialism is more straightforward, although an allegorical mode of 
narration is used as well. Here, Tchibamba goes back to the beginnings of colonization: the period of exploration, conquest and the État indépendant du Congo (18851908). These texts can already count as fictionalized memory work across time, as Tchibamba and his generation did not experience this period personally, although their parents and grandparents did. In "N'Gobila des Mswata ou Mistantèle," the author chooses the time of the explorations of Henry Morton Stanley as a setting. He questions the myth of the peaceful conquest of Central African territories that has been propagated by colonial ideology. $\mathrm{N}^{\prime}$ Gobila, the hero of the story who will grow into an allegorical figure of resistance, refers to a historic personality. According to Stanley's travelogue, The Congo and the Founding of its Free State. Story of Work and Exploration (1885), Gobila was an important "chief" in the region of the upper Congo and became his ally and counsellor when the first Western explorers started to sign contracts with local potentates in order to legitimise colonization. Depicted as a naïve collaborator of early colonialism, he is called, with certain affection, "Papa Gobila" by Stanley.

Gobila already appears in fiction for the first time in 1898, in Joseph Conrad's novelette An Outpost of Progress, the satiric story of two unsuccessful Belgian colonisers in the Congo Free State. In this plot, Gobila is at first cooperative with the founders of a colonial station on his territory, receiving them with hospitality and interest. Nevertheless, when he learns that they buy slaves in order to carry out work for the station, he stops all contact with them and moves away with all the members of his village. Deprived of food, the colonisers' destiny is slow starvation and mental decay that will climax in the mutual killing of the two "representatives of civilisation" as they are ironically called throughout the text. In Conrad's short story, Gobila is already an ambiguous figure, practising a form of passive resistance to the colonial system, which is gradually being implemented by the Europeans.

In Lomami Tchibamba's text, $\mathrm{N}^{\prime}$ Gobila turns into an active and heroic opponent of colonisation. He receives the "Mistantèle" (nickname for the European administrator) and his soldiers with hospitality, but when they begin to treat him and his people with disrespect, he cuts off their food supply. The intertextual link to Conrad is obvious, so far, but the conflict leads much further in Tchibamba's rewriting, which focuses on N'Gobila as a personality endowed with agency. When the administrator uses violence against the village via his soldiers, N'Gobila decides to destroy the colonial station. Through magical power, his warriors become leopard men and effectively win the battle against the colonial representatives: the European and his African auxiliaries are killed. The leopard men as well as N'Gobila can be read as allegories of the African power of resistance, which has not been erased from the collective memory of the Congolese. ${ }^{7}$

At the end of the story the narrator makes an interesting self-ironic statement, when he says: 
This narration is part of the arsenal of the glorifying lies that have for a long time crowned the terrible epos of Mfumu N'Gobila, deified king of the Mswata and the Arufu. [...] The task of the narrator, eternal liar whose atavistic mission it is to hawk and perpetuate the legends of the territory, stops here. On my behalf, I have spoken. (Tchibamba 1972: 90) ${ }^{8}$

Here Lomami Tchibamba uses humour as a weapon against the potential critics of his story and clarifies that he does not aspire to any form of historical truth, but that his text constitutes literary fiction as a conscious, though subjective, rewriting of memory - against the grain of official history and colonial literature. Drawing on both oral and colonial literary sources in a double movement of continuation and contestation, Tchibamba's text exemplifies the tension between what Vellut (1984: 82) has called the two myths in the historiography of the conquest of the Congo: "Le mythe résistantialiste présente l'image inversée du mythe pacificateur" ("The myth of resistance represents the turned around image of the myth of pacification").

The second text of the volume, "La récompense de la cruauté," poses the problem of alterity and violence. It relates the reactions of representatives of the colonial order being confronted with an extraordinary creature: a huge monster that is half-reptile, half-human. Through this allegory of a human monster, the lack of recognition of and tolerance for the other in colonial encounters is put into a mise en abyme. The anthropologist Johannes Fabian has analyzed the writings of the early explorers of Central Africa under this aspect of "recognition." Underlining that the living conditions and habits in European rural areas of the $19^{\text {th }}$ century did not radically differ from African rural life at the same period, he points out the astonishing, systematic refusal of recognition of the Other - Africans in this context - as human beings (Fabian 1999). In fact, if Africans had been recognised as human equals, the violence of conquest and submission would not have been possible.

Tchibamba's story is set in the forest of Kilimani, close to Kinshasa, and the colonial station next to it. The reader learns that a mysterious monster, who speaks Kikongo, has lived in the forest for ages. The inhabitants of the region just tolerated its presence. Pushed by the Catholic missionaries who believe that this must be a devilish creature, the colonial administrator organises a campaign of "exploration and military action" against the supposed "Belzebuth de Kilimani" (Tchibamba 1972: 10). The members of this expedition constitute a microcosm of the colonial society: the provincial secretary and the territorial administrator represent political power. The sciences are present with a zoologist and an archaeologist; a Catholic priest represents religion, and finally, four European officers and forty African soldiers of La Force Publique make up the military section. There exists an ideological split within the European members of the group, as the political and scientific forces represent "ratio" and "logos" whereas the priest stands for "religion" and "spirituality," dismissed as irra- 
tional by the former. The African soldiers play the difficult role of intermediaries between the population and colonial power. Although they carry out the will of the colonisers, they secretly share the feelings of the population who ask: "They asked themselves if the white had really seriously reflected the situation and if they understood that their power had its limits in certain domains" (Tchibamba 1972: 11). ${ }^{9}$ The African subjects thus doubt the "ratio" of the Europeans whose deeds seem completely out of context.

When they finally find the "monster" - after a long expedition into the wilderness, which is reminiscent of colonial conquest travelogues and Heart of Darkness - it is described as a creature with human features:

An extraordinary creature: it had a really human head, but which was surprisingly big as if four or five heads of people had melted together. [...] its brown eyes had a soft gaze, somehow nostalgic [...], the rest of the body made the impression to be a big mass, covered by large scales, contrary to the neck which was naked. (Tchibamba 1972: 25) ${ }^{10}$

Immediately, the scientists try to classify the creature, but fail. While one part of the expedition wants to catch the 'human monster' alive, the administrator pleads for violence: "In my opinion, it would be wise if we fired a good dozen of bullets into his pseudo-human oversized head" (Tchibamba 1972: 27). ${ }^{11}$ This cynical language covers the fear of the Other, different though human. The power of violence takes over and the creature is shot down. The agony until its death is described in pathetic words, insisting on the douloureux visage humain (the painful human face, Tchibamba 1972: 37). However, the vengeance - resonant of the title of the story - follows immediately: while dying, the creature starts to vomit a kind of black poisonous breath that will cover all the members of the expedition and cause them to die in terrible agony. Lomami Tchibamba has a predilection for such allegorical apocalyptical endings of colonial societies, as we find similar tableaux in Ngando (a flood) as well as in "N'Gobila des Mswata" (the destruction of the station) and in "La récompense de la cruauté." More than a mere fantasizing about the turning around of power relations, these allegories are a warning against the fact that a society built on violence will also end violently - a prophecy fulfilled in the case of the Belgian Congo if we consider the happenings of the so-called Congo crisis of the 1960s.

The violent death of the Other in "La récompense de la cruauté" is an allegorical narration that symbolizes the incapacity of colonialism to deal with alterity. At the very moment of its death, using the biblical image of Golgatha's sun eclipse, Tchibamba draws on the Conradian metaphor of darkness, although it is devoid of any ambiguity here and clearly echoes the effects of colonial violence: "the sun which was radiant at this moment, veiled itself entirely, as if blown off: suddenly night fell down, taking everybody into a surprising darkness" (Tchibamba 1972: 38). ${ }^{12}$ 


\section{Body memory in fragmented writing: Thomas Mpoyi Buatu's La re-production}

In Congolese literature, from both sides of the river, the body is often used as the central site for the representation of not only physical, but also structural and psychological violence as well. The novels of Sony Labou Tansi (Nshimiyimana 2005, VeitWild 2005), but also the writing of Pius Ngandu Nkashama, with the above-mentioned Yakouta in particular, are important examples. The tortured body can be used to re-signify the violent past and to mirror the violent present as well, because the history of torture has never really been interrupted in the Congo, from the era of Leopold II up until today. Thomas Mpoyi-Buatu's novel La re-production, published during his French exile in 1986 (the same year as Tchibamba's Ngemena), traces the connections between the violence of the past and the present.

The novel is structured as a project of memory and writing. The frame narrative exposes the situation of an incarcerated and tortured teacher of philosophy, Meji Kena-Ushima, who starts to write a diary in prison: the text, which constitutes the major part of the novel. The Tchiluba name of the protagonist can be translated into "the intelligent one who speaks the truth" (Chiwengo 2006: 100). He has obviously been imprisoned because of his attempts to teach his pupils how to think for themselves, moved by his fierce position of refusal of any form of reproduction of knowledge - hence the title of the novel. Transgressing generic conventions, the text combines elements of an autobiographical diary, a philosophical manifesto and a loose succession of anecdotes, oscillating between a pathetic and an ironic, even cynical style. ${ }^{13}$ Three levels of violence are present in this text, where they constantly interfere with each other: (a) the colonial violence since Leopold II and throughout the Belgian colonial regime, (b) the present violence of the dictatorial regime, and (c) sexual violence as a sign for corrupted human relationships in the represented society. In this text, which is constantly reflecting its own act of being written, several narrative threads become apparent only to be disrupted again, reappear at unexpected moments and intermingle with each other. This fragmented narration contains the stories of the protagonist and first-person narrator Kena, his sister Yowa, who chooses prostitution as a means to protest against the conventional role of women as mothers, as well as stories of some of her eccentric clients and comments on the history of slavery and colonialism, especially in Kinshasa. As Chiwengo (2006: 101) has aptly put it: "Crossing literary frontiers, historical spaces, disciplines and sexualities, La reproduction hopes to engender a liberating space apt to dismantle corrupt, violent and totalitarian regimes." ${ }^{14}$

My reading will focus on the aspect of colonial violence as one of the dominant aspects throughout the novel. The traumatic experiences of colonialism seem almost to be forgotten in the represented society. This collective amnesia constitutes a flagrant gap in the otherwise endless cycle of reproduction that dominates the human condition (Dehont 2006). Ken becomes obsessed by the idea of reconstructing the 
colonial past, not by accumulating historical facts, but by telling the story of enslaved, violated and fragmented bodies in Congo's colonial past, while at the same time his own body goes through the no lesser violent tortures of the present regime. Thus, past and present, individual and collective experiences interfere constantly. Bound to the closed space of the prison cell, two metaphors of movement, "a walk through the city of Kinshasa" and "a navigation of the river Congo," allow the narrator to pursue a fragmented reconstruction of the violent history carried out on the bodies of African subjects. ${ }^{15}$

Throughout the text, the famous chopped hands of Leopold's Congo Free State and la chicotte, the whip, which was widely used in the Belgian Congo, function as collective symbols of the violence of colonialism. Stressing the link between colonial ideology and physical violence, the chicotte is ironically metaphorised as "this civilizing instrument par excellence whose advantage was to mark the body directly in order to better encrust the civilizing seed into it" (Mpoyi-Buatu 1986: 151) ${ }^{16}$ The submission of Black African bodies is interpreted as the quintessence of colonialism, as it materializes in its most consequent way the chauvinistic Othering of the colonised:

"Civilization" did not tolerate any darkness. Wasn't one in the "heart of darkness"?

After having stripped the autochthones of their land, nothing more remained but

to strip them of their bodies. Miserable bodies, pitifully dark... Foolish bodies,

mutilated bodies... Colonization in the tropics had turned the body into a concept.

To wipe it off. Black bodies. Absolute evil. (Mpoyi-Buatu 1986: 150) ${ }^{17}$

The hint to Joseph Conrad here is one example of the many allusions to the colonial archive throughout the text, constantly reminding the reader that cultural artefacts strongly supported the process of Othering and conquering. As to the post-colonial subject, represented through the voices of Kena and his sub-narrators, the traumatic history of bodily fragmentation and domestication can only be expressed via a kind of hallucinated writing that tries to relive the pains of the past. This is why memory is so closely tied to the body, as the narrator repeats several times, "My body remembers, my body suffers it" (Mpoyi-Buatu 1986: 193) ${ }^{18}$ In the context of the novel's philosophical stance indebted to Nietzsche, this focalization on the body with its inscriptions of wounds, mutilations and scars can be understood in the sense of Nietzsche's concept of the Körpergedächtnis, a memory of and through the body (Assmann 1999: 245-47). ${ }^{19}$

Another narrator of parts of the book is Boris, a ten year-old child, but already very old because of the burden of memory. While geographically Kena narrates the history of Kinshasa, Boris tells that of the "incredible epos" (131) of the eastern parts of the country. His book project is entitled Une terre vacante: Le Congo (A vacant land: the Congo), thus making use of well-known colonial rhetoric. His intertexts are Joseph Conrad's Heart of Darkness, Tippu Tip's autobiography in Swahili, the travel writings of Stanley and Arthur Vermeersch's book La Question congolaise (The Congolese ques- 
tion), published by the Jesuit in Brussels in 1906 at the climax of the debate about Leopold's misuse of the Congo. All these texts are re-read in a critical way by Boris, whom the reader suspects to be but another mask of Kena himself, dismissing the authors as hypocrites. For instance, although Vermeersch made a critical statement about the colonial policy of his time, the narrator responds to him as follows: "to the question he raises 'rubber or civilization?' I I answer: 'clergy or colonist?' It is true that in this precise case they are buddies like pigs" (Mpoyi-Buatu 1986: 57-58). ${ }^{20}$ The Conradian paradigm of colonial "madness" as an effect of Africa upon Europeans is equally mocked and dismissed as an inappropriate excuse for racism and violence.

The levels of colonial and post-colonial violence are constantly blurred in the novel, which does not follow a proper chronology, but moves through times and spaces in a discontinuous way. The inner pain of the narrator is generated by his consciousness about the continuity of violence over many generations. While he gets himself flogged with the chicotte and violated by some soldiers in prison, his thinking is focused on the absurdity of a cyclic continuity: "Innumerable centuries of grey constraint. Ignorance of brackets. Resumptions of latencies. Independences. Where? When? Gaps of nothing! Obscene prolongations!" (Mpoyi-Buatu 1986: 11). ${ }^{21}$

The history of Kinshasa's architecture is another point of reference for the continuity of colonial structures. If during the time of the Belgian Congo the capital was divided according to a quasi apartheid regime into the modern European city and the simply-structured cités indigènes for Africans, which were paradoxically called les Belges, at present the newly enriched and powerful elites protect their commercial and private spaces against the majority of impoverished people, thus imposing new boundaries. The prestige function of representative buildings like the Palais du Peuple and Palais Présidentiel can also be compared to Leopold's constructions of the Palais Royal de Bruxelles, Palais de Justice etc., of which it has been said that they were built with the blood of the Congolese rubber workers. This is why, looking at the new presidential district of Nsélé, the narrator is again reminded of the fragmentation of bodies and a flagrant case of mimicry:

Here in Nsélé, we are decorating the frontages according to the commercial rule

[...] Pieces of arms by here, pieces of legs by there: arms and legs spread and one obtains an attitude. [...] But how come that all this gives the impression to be a pale imitation of oneself by oneself thanks to the mediation of a commercial third? Who said that one died of imitation?" (Mpoyi-Buatu 1986: 191).22

Kena concludes that the Congo is still administrated like a land without citizens who have to be taken into consideration, une terre vacante, the cult and the megalomania of the president being in direct affiliation with the personal absolutism in the early period of colonisation. Reflecting on systematic corruption in the state system, he further addresses an ironic prayer to the King who introduced capitalism in the 
Congo: "Heal to our Holy Father Leopold who knew how to open these horizons to us [...]. The kings resemble each other. They appropriate. They appropriate. The same reign continues [...]" (Mpoyi-Buatu 1986: 205). ${ }^{23}$

The protagonist's resistance to the absurdities of history and present times lies in his categorical refusal of any form of reproduction, biological or intellectual. He refuses to "produce" children that would be born into a corrupted and violent world. His sister and female alter ego rejects the role of the mother as well. Whereas the Mother was especially valued in the Zairrean context through the quasi-religious cult, which Mobutu imposed in honour of his own mother, the brother and sister of the novel remember the spectacle of the body of their own biological mother, exhausted by too many maternities and abortions, with disgust and anguish. Kena radicalises his philosophical stance through his homosexual, incestuous and sodomite sexual practices; a sexual life that consequently breaks with the norms of heteronormativity, and that must be understood as a form of aspiration to the Nietzschean concept of supermorality as a condition for total freedom (Mouralis 1987, Dehont 2006). Yowa chooses prostitution as a means of survival beyond the traditional female role, in spite of the violence she experiences in this profession. Through her body, she does also participate in the memory work of her brother, assuming colonial sadism in her own flesh:

But work here is related to the chicotte. Therefore I feel the desire to torture my breasts to test the same impression. I say that as if I knew the times. But my flesh feels it deeply. I bet that these idiots from abroad had erections while they flogged ... Men of course ... As for the women, they reached climax while thinking of their men, these men who tortured bodies of men. (Mpoyi-Buatu 1986: 82) ${ }^{24}$

Sexual violence against Congolese women by Belgian colonialists and paedophilic practices of missionaries are yet other traces of collective memory that haunt the novel. The humiliating practice of the attesting of "civilisation" via the evaluation system of the immatriculation des évolués (registration of the evolved) is also exposed (Riesz 1998: 335-39). But in contrast to Tchibamba's pathetic accusation in Ngemena, MpoyiBuatu uses cynicism when he speaks of the immatriculé enculé (registered asshole).

At the end of the novel the soldiers destroy Kena's journal and he remains with his tortured body as the only site of communication. "They had seized my diary. Flown away the beautiful dream of discontinuity. Duration on paper. Duration-paper. Writing is fright. Traces. Memory. Critic. Subversions. Destruction. Only my blood remains. I find myself there" (Mpoyi-Buatu 1986: 243). ${ }^{25} \mathrm{He}$ continues to write directly with and on his body, using his own blood and skin, his body and his writing becoming thus a synecdoche for the violent history and present of the Congo as well as its memory. The text thus resumes and radicalises the concept of the body as a site of memory. 


\section{Conclusion}

African literature in French, as in other ex-colonial European languages, is addressed to a double audience: the African public as well as a European readership. When Congolese writers speak out about structural and physical violence during colonial times, they address the collective memory of their colonised people and, at the same time, subvert colonial discourses, which are still inherent in Occidental literature about the Congo today. Authors, from both banks of the river Congo, use different writing strategies to approach the subject. Techniques of documentary, allegorical and fragmented narration as well as the use of intertextuality can be identified as dominant schemes. The two authors whose texts have been analysed in this paper represent shifting stylistic patterns in two distinct generations of Congolese writers. Lomami Tchibamba elaborates powerful allegories in order to provide counter-narratives to colonial texts of conquest and domination. Using elements of Congolese oral literature and history, he combines a realistic and a mythical worldview, which reflects the complexity of the colonial situation and the anguish of the colonised. The apocalyptical endings of his stories predict the violent end of the colonial project. In Thomas Mpoyi-Buatu's novel La re-production, the burden of colonial violence is inscribed into the suffering body of the protagonist/narrator, whose memory embraces the collective past while he is tortured by the postcolonial dictatorial regime. Ruptures, multivocality, decentred chronology and spatiality characterise this text as an example of fragmented narration that reflects the traumatic experience of violence.

\section{Notes}

1 This paper was written during my research stay at Université Laval in Québec in 2008. I would like to thank the Alexander von Humboldt-Stiftung for the generous scholarship and Justin Bisanswa for his hospitality and scientific inspiration.

2 It must of course be taken into consideration that an increasing percentage of the literary output by Congolese authors is today written in exile, outside of the Congo.

3 The anthropological and historical works of Johannes Fabian and Bogumil Jewsiewicki have proven the vivacity of memory about colonial violence in different cultural expressions, as for instance painting (Fabian 1996, Jewsiewicki 2001) and life narration (Jewsiewicki 1993), to name but a few of their publications. The recent book How Belgium Colonized the Mind of the Congo: Seeking the Memory of an African People by Lieve Spaas also gives insight into orally transmitted memories of colonization in the Congo. My focus here is on fictional literature only, although it is of course useful to consider different forms of cultural expression as complementary.

4 In literature, the historical myth of Doña Béatrice has been turned into a drama by the Ivorian author Bernard Dadié (1970).

5 "l'un réel, l'autre mythique, qui, parce qu'imbriqués l'un dans l'autre, nous restituent avec justesse un univers où le jour et la nuit, la vie et la mort, le visible et l'invisible se coordonnent, voire s'agrègent symboliquement en une cohésion étroite." All translations from French into English are mine.

6 "l'auteur a surchargé son texte d'éléments empruntés à la vie quotidienne de la "Léopoldville" du temps colonial, recouvrant ainsi la véritable angoisse qui marque l'existence du colonisé"

7 "Leopard men" as agents of secret societies, who often carried out murders, were known in different parts of the Congo during the 19th and 20th centuries. Considered a potential menace 
to colonialism, their "magical power" fascinated colonial artists and writers (see Halen 1988). Although historically, there is no record of any murder of Europeans by leopard men, Tchibamba makes strategic use of their threatening reputation.

8 “Ce récit vient de l'arsenal de menteries apothéotiques qui ont longtemps auréolé la terrible épopée de Mfumu N'Gobila, roi déifié des Mswata et des Arufu. [...] Ici s'arrête la part du narrateur, éternel menteur, à qui échoit l'atavique mission de colporter et de perpétuer les légendes du terroir. Pour ma part, j'ai dit."

9 “On se demanda si les Blancs avaient sérieusement réfléchi et s'ils comprennent seulement que leur force avait des limites dans certains domaines."

10 "Une créature extraordinaire: elle avait une tête véritablement humaine mais d'une grosseur surprenante qu'on pouvait comparer à quatre ou cinq têtes d'hommes fondues en une seule. [...] ses yeux marrons avaient un regard doux, quelque peu nostalgique [...], le reste du corps donnait l'impression d'une grande masse, couvert de larges écailles contrairement au cou qui était nu."

11 "A mon avis, il est prudent qu' on lui loge une bonne dizaine de balles dans sa monstrueuse caboche pseudo-humaine."

12 "le soleil, alors radiant, se voila entièrement, comme éteint: la nuit tomba brusquement, plongeant tout le monde dans une obscurité surprenante."

13 The links to Nietzsche's concepts of supermorality and the sovereign individual (as elaborated in Über Wahrheit und Lüge im außermoralischen Sinn (On truth and lie in an extra-moral sense, 1872), Die fröhliche Wissenschaft (The gay science, 1882) and Zur Genealogie der Moral (On the genealogy of morals, 1887), present in the paratext (citations from p. 6) and throughout the novel, have been analysed by Mouralis (1987) and Dehont (2007) respectively. Dehont adds a psychoanalytical reading dimension by applying Freudian concepts to the text.

14 "En traversant les frontières littéraires, les espaces historiques, les disciplines et les espaces sexuels, $L a$ re-production espère engendrer un espace libérateur susceptible de démanteler les régimes corrompus, violents et totalitaires."

15 The reading of Chiwengo (2006) traces the spatial movements of the text and elaborates their transversal symbolism as part of a liberating process.

16 "cet instrument civilisateur par excellence dont l'avantage consistait à faire des entailles à même le corps afin de mieux y incruster la graine civilisatrice."

17 "La 'civilisation' ne tolérait aucune obscurité. N'était-on pas au 'cœur des ténèbres'? Après avoir dépouillés les autochtones de leurs terres, il ne restait plus qu'à les dépouiller de leurs corps. Corps miséreux, pitoyablement obscurs... Corps insensés, corps mutilés... La colonisation sous les tropiques avait fait du corps un concept. A expurger. Corps noirs. Mal absolu."

18 "Mon corps s'en souvient, mon corps en souffre."

19 About the uses of the concept of body memory in recent cultural and literary studies see Bannasch \& Butzer (2007).

20 “A la question qu'il pose 'caoutchouc ou civilisation?', je réponds: 'ensoutané ou colon?' Il est vrai qu'en ce cas précis ils sont copains comme cochons."

21 "Innombrables siècles de servitude grisée. Ignorances de parenthèse. Reprises de latences. Indépendances. Où ? Quand ? Béances du néant ! Prolongements obscènes !"

22 "Ici à Nsélé, nous, on décore les façades suivant la règle marchande... Des bouts de bras par ici, des bouts de jambes par-là : des bras et des jambes écartés et l'on obtient une attitude. [...] Mais d'où vient que tout ça donne l'impression d'une pâle imitation de soi par soi grâce à la méditation d'un tiers marchand ? Qui a dit qu'on mourait de mimétisme?"

23 "Grâces soient rendues à notre Saint-Père Léopold qui a su nous ouvrir de ces horizons.... Les rois se ressemblent. On s'approprie. On s'approprie. Le même règne continue...."

24 "Mais le travail ici est lié à la chicotte. Ça me donne envie de me torturer les seins pour éprouver la même impression. Je dis ça comme si j'ai connu l'époque. Mais ma chair éprouve ça vivement. Je parie que ces cons d'étrangers devaient bander en chicottant... Les hommes bien sûr... Quant aux femmes, elles jouissaient en pensant à leurs hommes, à ces hommes qui martyrisaient des corps d'hommes."

25 “Ils s'étaient emparés de mon journal. Envolé le beau rêve de la discontinuité. De la durée sur papier. La durée-papier. L'écriture est frayeur. Traces. Mémoire. Critique. Subversions. Destruction. Ne reste que mon sang. Je m'y retrouve." 


\section{Works cited}

Abomo Maurin, M.-R. 1995. Ngemena ou la mise en scène de l'accusation dans le procès de la colonisation belge. Matatu. Journal for African Culture and Society, 13/14: 209-23.

Assmann, A. 1999. Erinnerungsräume. Formen und Wandlungen des kulturellen Gedächtnisses. München: C.H. Beck.

Bannasch, B. \& Butzer, G. (eds). 2007. Übung und Affekt. Aspekte des Körpergedächtnisses. Berlin, New York: Walter de Gruyter.

Bhabha, H. 1994. The Location of Culture. London: Routledge.

Chiwengo, N. 2006. L'autobiographie transgressive: la traversée dans La re-production de Mpoyi Buatu. Revue de l'Université de Moncton, 37 (1): 93-110.

Conrad, J. 1977 [1902]. An Outpost of Progress. In J. Conrad. Tales of Unrest. London Penguin Books, $83-110$.

Dadié, B.B. 1970. Béatrice du Congo. Paris: Présence Africaine.

Dehont, C. 2007. Histoire et éternel retour du Même dans La re-production de Thomas Mpoyi-Buatu. In Laurence Boudreault/Allaeddine Ben Abdallah (eds.). Recherches francophones. La pression du social dans le roman francophone. CIDEF: Québec, 151-59

Djungu-Simba, C. 2007. Les écrivains du Congo-Zaïre. Approches d'un champ littéraire africain. Metz: Université Paul Verlaine.

Dongala, E. 2001 [1987]. Le feu des origines. Paris: Le Serpent à Plumes.

Fabian, J. 1996. Remembering the Present. Painting and Popular History in Zaire. Berkeley: University of California Press.

Fabian, J. 1999. Remembering the Other: Knowledge and recognition in the exploration of Central Africa. Critical Inquiry, 26 (3): 49-69.

Gehrmann, S. 2003. Kongo-Greuel. Zur literarischen Konfiguration eines kolonialkritischen Diskurses. Hildesheim: Olms.

. 2005. Les littératures en marge du débat sur les "atrocités congolaises": de l'engagement moral à l'horreur pittoresque. Revue de littérature comparée, 79 (2): 139-60.

Halen, P. 1988. Une figure coloniale de l'autre: l'Homme-Léopard (sur Hergé, André Villers, Olivier de Bouveignes, José David, Henri Vernes). Les Cahiers des Para-littératures 2: 129-47. . 2004. Relire Ngando de Paul Lomami-Tshibamba (1948), cinquante ans après. In Lüsebrink, H.J. \& Städtler, K. (eds.). Les littératures africaines de langue française à l'époque de la postmodernité. État des lieux et perspectives de la recherche. Oberhausen: Athena, 59-77.

Hochschild, A. 1998. King Leopold's Ghost. A Story of Greed, Terror and Heroism in Colonial Africa. New York: Houghton Mifflin.

Jewsiewicki, B. (ed). 1993. Naître et mourir au Zaïre. Un siècle d'histoire au quotidien. Paris: Karthala. \& Planckensteiner, B. 2001. An/Sichten, Malerei aus Kongo, 1990-2000. Vienna: Springer.

Kadima-Nzuji, M. 1982. Préface. In Tchibamba, L. Ngando et autres récits. Kinshasa \& Paris: Éditions Lokolé \& Présence Africaine, 7-11.

. 1984. La littérature zaïroise de langue française (1945-1965). Paris: Karthala/ACCT.

Mpoyi-Buatu, T. 1986. La re-production. Paris: L’Harmattan.

Mouralis, B. 1987. Un roman "super-moral." La re-production de Thomas Mpoyi-Buatu. Présence Africaine 144: $18-31$.

Mulumba, J. 2007 [O]. L'évolué au Congo Belge, l'homme à l'identité en pièces. Mondes francophones. Revue mondiale des francophonies. <http://www.mondesfrancophones.com/espaces/Afriques/articles/ l-evolue-congo-belge/view > Accessed: 28.08.2008.

Nkashama, P. N. 1982. Le symbolisme saurien dans "Ngando" de Lomami Tchibamba. Présence Africaine 123: 153-87. 1995. Yakouta. Paris: L'Harmattan.

Nshimiyimana, E., 2005. Les corps mythiques de Sony Labou Tansi: figuration et "mnémotopie." Études françaises, 41 (2): 87-97.

Riesz, J. 1998. Französisch in Afrika - Herrschaft durch Sprache. Frankfurt: IKO.

Riva, S. 2006. Nouvelle histoire de la littérature du Congo-Kinshasa. Paris: L'Harmattan.

Spaas, L. 2007. How Belgium Colonized the Mind of the Congo: Seeking the Memory of an African People. Lewiston, New York: The Edwin Mellen Press. 
Stanley, H. M. 1885 : The Congo and the Founding of its Free State. Story of Travel and Exploration. London: Heinemann.

Tchibamba L., 1972. La récompense de la cruauté suivi de N'Gobila des Mswata ou Mistantèle. Kinshasa: Éditions du Mont Noir.

1982 [1948]. Ngando et autres récits. Kinshasa and Paris: Éditions Lokolé and Présence Africaine. 1986. Ngemena. Yaoundé: Éditons du Clé.

2007. Ah! Mbongo [Ah! L'argent]. Paris: L'Harmattan.

Thomas, D. 2002. Nation-building, Propaganda and Literature in Francophone Africa. Bloomington and Indianapolis: Indiana University Press.

Tshitungu Kongolo, A. 2002. Colonial Memories in Belgian and Congolese Literature. Yale French Studies, 102: 79-93.

Veit-Wild, F. 2005. The grotesque body of the postcolony: Sony Labou Tansi and Dambudzo Marechera. Revue de littérature comparée, 79 (2): 227-39.

Vellut, J. 1984. La violence armée dans l'État indépendant du Congo. Ténèbres et clartés dans l'histoire d'un état conquérant. Cultures et développement. Revue internationale des sciences du développement, 16 (3/4): 671-707. 